\title{
PENGARUH PENGGUNAAN MODEL DISCOVERY LEARNING TERHADAP KETERAMPILAN MENULIS KARANGAN ARGUMENTASI SISWA KELAS X SMA NEGERI 3 PARIAMAN
}

\author{
Oleh: \\ Elsa $^{1}$, Syahrul ${ }^{2}$, Tressyalina ${ }^{3}$ \\ Program Studi Pendidikan Bahasa dan Sastra Indonesia \\ FBS Universitas Negeri Padang \\ email: Elsalailatunrozipahhasibuan94@gmail.com
}

\begin{abstract}
In this study, theoretical concept of disovery learning are reviewed the influence model to the writing skills of argumentation of class X students of SMA Negeri 3 Pariaman. The data of this study is the result of the skill of writing the argumentation without and by using the treatment. The data was collected by giving learning of argumentation by using discovery learning model in experiment class. The test used in this study is a test performance to students in the form of writing test of argumentation. Abstract writing skill writing skill and using treatment is compared to see the effect of discovery learning model by using t-test formula. The result of the research shows that (1) writing skill of argumentation of class $X$ students of SMA Negeri 3 Pariaman without using discovery learning model is in qualification Enough, (2) writing skill of argumentation using discovery learning model of class $X$ students of SMA Negeri 3 Pariaman is in Good qualification, (3) based on t-test, it can be concluded that there is significant influence to the discovery learning model in learning writing writing argumentation of class X students of SMA Negeri 3 Pariaman.
\end{abstract}

Kata kunci: Pengaruh, penggunaan model discovery learning, menulis karangan argumentasi

\section{A. Pendahuluan}

Keterampilan menulis sangat penting bagi setiap siswa terutama pada siswa Sekolah Menengah Atas (SMA). SMA merupakan sekolah vokasi yang mengedepankan keterampilan siswa terutama keterampilan menulis. Pembelajaran keterampilan menulis perlu memiliki banyak ide, ilmu pengetahuan,dan pengalaman hidup. Hal tersebut merupakan modal dasar yang harus dimiliki dalam kegiatan menulis. Pemunculan pemikiran siswa yang kritis perlu diciptakan melalui kegiatan keterampilan menulis, khususnya keterampilan menulis argumentasi.

Selain itu, keterampilan menulis menuntut siswa agar lebih kreatif dalam menata pola pikirnya. Dengan menulis, siswa terlatih dalam mengungkapkan gagasannya agar tulisan yang dihasilkan siswa dapat diterima oleh pembaca. Keterampilan menulis juga menuntut siswa untuk mempunyai pengetahuan yang luas. Namun, kenyataan yang dihadapi dalam pembalajaran bahasa Indonesia untuk keterampilan menulis terdapat beberapa kendala dan masalah.

Menurut Rahzanie (2011: 4) penyebab rendahnya karangan argumentasi siswa terdapat pada media pembelajaran yang kurang dimanfaatkan secara maksimal oleh guru sehingga

\footnotetext{
${ }_{1}^{1}$ Mahasiswa Penulis Skripsi Prodi Pendidikan Bahasa dan Sastra Indonesia untuk wisuda periode September 2017

2 Pembimbing I, dosen FBS Universitas Negeri Padang

3 Pembimbing II, dosen FBS Universitas Negeri Padang
} 
membuat siswa bosan, dan siswa kurang memiliki wawasan tentang fakta-fakta yang terjadi di sekitar kehidupan mereka. Sehingga karangan yang dihasikan kurang baik dan berbobot.

Menurut Idris (2014: 2) ada beberapa faktor yang menyebabkan pembelajaran menulis karangan argumentasi tidak mencapai hasil yang diharap. Faktor tersebut, yaitu (1) siswa belum mampu menulis karangan argumentasi berdasarkan media yang diberikan, (2) siswa belum mampu menemukan data-data dan fakta yang diperlukan untuk menulis, dan (3) siswa belum mampu mengorganisasikan data dan fakta menjadi sebuah paragraf.

Masing-masing faktor tentunya memiliki kelemahan-kelemahan, pada faktor pertama mengenai kemampuan siswa menulis karangan argumentasi berdasarkan media yang diberikan. Kebanyakan siswa tidak memperhatikan media yang diberikan oleh guru saat mengajar, karena media yang diberikan kurang menarik dan siswa juga kurang menyadari hal-hal yang penting dalam media yang diberikan sebagai bahan untuk menulis karangan argumentasi. Pada faktor kedua, siswa belum mampu menemukan data-data dan fakta-fakta yang diperlukan untuk menulis karangan argumentasi. Siswa kurang peka terhadap informasi-informasi yang disajikan dari media maupun yang ada di lingkungan sekitar siswa, sehingga siswa kesulitan untuk menullis. Siswa lebih terbiasa hanya merangkaikan saja kalimat menjadi paragraf, dibanding siswa harus membuat sendiri. Siswa diharuskan untuk menemukan sendiri bahan yang akan ditulis dalam karangan argumentasi. Faktor ketiga, siswa diharapkan mampu mengorganisasikan data dan fakta menjadi sebuah paragraf.

Menurut (Ambarwati, Y., Andayani, dan Rakhmawati, A .2015: 4) karangan argumentasi adalah ragam wacana yang dimaksudkan untuk meyakinkan pembaca mengenai kebenaran yang disampaikan oleh penulisnya. Tujuan tulisan argumentasi adalah meyakinkan pembaca atas pendapat yang dikemukakan, maka penulis akan menyajikan secara logis, kritis, dan sistematis bukti-bukti yang dapat memperkuat keobjektifan dan kebenaran yang disampaikan sehingga dapat menghapus konflik dan keraguan pembaca terhadap pendapat penulis.

Menurut Ermanto dan Emidar (2015:160) karangan argumentasi adalah karangan yang berisi penjelasan, temuan atau keyakinan dengan pemberian alasan, data, atau fakta. Senada dengan pendapat di atas, Darmayanti, (2014:144) menyatakan karangan argumentasi adalah karangan yang mengandung argumen atau pendapat, data, dan fakta-fakta yang dapat dibuktikan kebenarannya. Gagasan kritis siswa merupakan faktor penentu tingkat kualitas paragraf argumentasi.

Berdasarkan pendapat tersebut dapat disimpulkan bahwa argumentasi adalah suatu tulisan yang berusaha mempengaruhi pendapat dan sikap orang lain melalui fakta-fakta. Melalui tulisan argumentasi pembaca diyakini dengan pembuktian dan alasan yang tepat dan mempunyai hubungan yang logis atara fakta-fakta tersebut. Tulisan argumetasi berusaha membuat pembaca yakin dan percaya sehingga sependapat dengan yang diinginkan penulis.

Keterampilan siswa dalam menulis karangan argumentasi dapat dilihat dari kelengkapan pengembangan karangan argumentasi. Pertama, teknik pengembangan karangan argumentasi (pendahuluan, tubuh argumen, dan simpulan). Kedua, pemaparan fakta sebagai bukti. Ketiga, ketepatan penggunaan Ejaan Bahasa Indonesia (EBI). Menurut Mizani (2015: 19) teknik pengembangan karangan argumentasi ada tiga, yaitu (1) pendahuluan, (2) tubuh argumen, dan (3) simpulan. Pendahuluan berisi tentang pembahasan pentingnya persoalan itu dibahas saat ini. Tubuh argumen berisis pembahasan masalah dengan menyajikan fakta-fakta. Simpulan berisi tentang kesimpulan-kesimpulan suatu pembahasan.

Kedua, pemaparan fakta sebagai bukti. Darmayanti (2014: 176) menyatakan karangan argumentasi adalah karangan yang pola pengembangannya berdasarkan argumen yang menyertakan fakta-fakta. Karangan argumentasi mengahadirkan informasi tentang suatu hal secara apa adanya lalu dikelompokkan dan dianalisis secara sistematis sehingga dapat menjelaskan suatu hal secara rinci.

Ketiga, ketepatan penggunaan Ejaan Bahasa Indonesia (EBI). Pentingnya penggunaan ejaan dalam sebuah tulisan disebabkan ejaan merupakan aturan dalam memindahkan bunyi bahasa ke bentuk tulisan. Menurut Hosnun (2006:16) mengungkapkan bahwa ejaan adalah kaidah-kaidah 
cara menggambarkan bunyi-bunyi (kata, kalimat dan sebagainya) dalam bentuk tulisan (hurufhuruf) serta penggunaan tanda baca. Menurut Semi (2009:151), ejaan adalah seperangkat sistem yang digunakan dalam memindahkan bahasa lisan kedalam bahasa tulis. Dalam menganalisis tulisan siswa khususya menulis teks anekdot, penggunaan EBI hanya menggunakan pemakaian huruf kapital, penulisan kata, dan penggunaan tanda baca.

Sejalan dengan pendapat Gani (2012: 69) ejaan adalah seperangkat aturan di dalam melambangkan bunyi-bunyi ujaran, yaitu bunyi-bunyi dalam bahasa Indonesia. Berdasarkan pendapat para ahli tersebut dapat disimpulkan bahwa ejaan adalah seperangkat aturan atau kaidah-kaidah yang digunakan dalam memindahkan bunyi bahasa ke dalam bentuk bahasa tulis atau tulisan. Ketepatan penggunaan ejaan yang benar adalah suatu keterampilan yang penting dikuasai bagi penulis atau pengguna bahasa tulis dalam memindahkan bunyi bahasa ke dalam bentuk tulis. Ketidaktepatan penggunaan ejaan dalam bahasa tulis akan mengahasilkan tulisan yang kurang baik dan makna yang tidak jelas.

Berdasarkan pengamatan yang telah dilakukan di SMA Negeri 3 Pariaman, siswa kelas X masih menemui beberapa kendala dalam menulis karangan argumentasi. Kendala tersebut antara lain (1) siswa dalam menulis karangan argumentasi belum sesuai dengan teknik pengembangan karangan argumentasi, (2) siswa dalam menulis karangan argumentasi belum mampu memparkan fakta-fakta yang ada sebagai bukti, (3) siswa belum mematuhui ketepatan penggunaan Ejaan Bahasa Indonesia (EBI), dan (4) model discovery learning belum pernah digunakan. Untuk mengatasi permasalahan tersebut, siswa kelas X SMA Negeri 3 Pariaman tersebut diberikan suatu perlakuan yaitu penggunaan model discovery learning terhadap keterampilan menulis karangan argumentasi.

Model pembelajaran discovery learning sangat baik jika diterapkan dalam pembelajaran menulis karangan argumentasi. Siswa terlihat lebih antusias, lebih aktif, dan lebih termotivasi dalam proses pembelajaran dengan menggunakan model discovery learning karena siswa merasa lebih tertantang untuk menemukan dan merumuskan masalah baik secara kelompok atau individu. Hal ini sejalan dengan pendapat Tumurun (2016; 103), model discovery learning merupakan model model pembelajaran yang mampu untuk mengembangkan keterampilan berpikir kreatif, diantaranya menemukan masalah dan merumuskan masalah. Selain itu model discovery learning adalah metode mengajar yang mengatur pengajaran sedemikian rupa sehingga anak memperoleh pengetahuan yang sebelumnya belum diketahuinya tanpa pemberitahuan langsung, sebagian atau seluruhnya ditemukan sendiri (Supriyanto, 2014: 167).

Model pembelajaran discovery learning merupakan salah satu model pembelajaran dimana guru tidak langsung memberikan hasil akhir atau kesimpulan dari materi yang disampaikannya. Hal ini sejalan dengan pendapat Muhamad (2016: 12), model discovery learning adalah proses belajar yang di dalamnya tidak disajikan suatu konsep dalam bentuk jadi (final), tetapi siswa dituntut untuk mengorganisasi sendiri cara belajarnya dalam menemukan konsep. Semua siswa memiliki memiliki potensi kreatif yang harus dikembangkan agar mereka mampu hidup penuh gairah dan produktif dalam melakukan tugas-tugasnya, maka kreativitas siswa harus dikembangkan secara optimal dalam situasi belajar mengajar dengan menggunakan metode pembelajaran yang tepat.

Menurut Widianyana (2014: 11) dengan penerapan model discovery learning untuk meningkatkan pemahaman konsep IPA dan sikap ilmiah siswa terdapat perbedaan nilai ratarata. Berdasarkan penelitian tersebut dapat disimpulkan bahwa terdapat pemahaman konsep dan sikap ilmiah siswa yang signifikan antara kelompok siswa yang belajar dalam model discovery learning dengan kelompok siswa yang belajar dengan model pengajaran langsung.

Selain itu, Rudyanto (2012: 8), menyatakan bahwa pembelajaran matematika materi bangun ruang dengan menggunakan perangkat pembelajaran model discovery learning dengan pendekatan saintifik bermuatan karakter dinyatakan efektif karena (1) kemampuan berpikir kreatif siswa tuntas secara individual dan mencapai ketuntasan klasikal, (2) rata-rata kemampuan berpikitr kreatif kelas yang mendapatkan pembelajaran dengan model discovery learning dengan pendekatan saintifik dengan bermuatan karakter lebih baik daripada rata-rata 
kelas kontrol yang mendapatkan pembelajaran ekspositori, (3) adanya peningkatan sedang kemampuan berpikir kreatif, dan (4) adanya pengaruh yang signifikan antara karakter rasa ingin tahu dan keterampilan mengkomunikasikan terhadap kemampuan berpikir kreatif siswa.

Bruner (dalam Hosnan, 2014:281) mengatakan bahwa discovery adalah metode belajar yang mendorong siswa untuk mengajukan pertanyaan dan menarik kesimpulan dan prinsipprinsip umum secara praktis. Selanjutnya, Bell (dalam Hosnan, 2014:281) mengungkapkan bahwa belajar penemuan (discovery) berarti belajar yang terjadi sebagai hasil dari siswa memanipulasi, membuat struktur dan mentransformasikan informasi sedemikian sehingga ia menemukan informasi baru.

Senada dengan pendapat di atas, Hosnan (2014:282) juga menyatakan bahwa model discovery adalah suatu model untuk mengembangkan cara belajar siswa aktif dengan menemukan sendiri, menyelidiki sendiri sehingga hasil yang diperoleh akan setia dan tahan lama dalam ingatan siswa. Dalam pembelajaran penemuan (discovery), siswa didorong untuk belajar sebagian besar melalui keterlibatan aktif mereka sendiri dengan konsep-konsep dan prinsip-prinsip, dan guru mendorong siswa untuk memiliki pengalaman dan melakukan percobaan yang memungkinkan mereka menemukan prinsip-prinsip untuk diri mereka sendiri (Wilcox dalam Hosnan, 2014:281).

Berdasarkan pendapat tersebut, dapat disimpulkan bahwa model discovery learning adalah suatu model pembelajaran yang terjadi apabila materi pelajaran tidak disajikan dalam bentuk finalnya tetapi siswa disuruh untuk mengorganisasi sendiri. Dalam pembelajaran penemuan, siswa didorong untuk terlibat aktif dalam proses pembelajaran.

Model discovery learning memiliki keunggulan dalam proses pembelajaran. Menurut Roestiyah (2008:20), ada tujuh keunggulan model discovery learning. Pertama, teknik ini mampu membantu siswa untuk mengembangkan, memperbanyak kesiapan, serta penguasaan keterampilan dalam proses kognitif siswa. Kedua, siswa memperoleh pengetahuan yang bersifat sangat pribadi sehingga dapat lama tertinggal dalam jiwa tersebut. Ketiga, dapat membangkitkan kegairahan belajar para siswa. Keempat, teknik ini mampu memberikan kesempatan kepada siswa untuk berkembang dan maju sesuai dengan kemampuannya masingmasing. Kelima, mampu mengarahkan cara siswa belajar, sehingga lebih memiliki motivasi yang kuat untuk belajar lebih giat. Keenam, membantu siswa untuk memperkuat dan menambah kepercayaan pada diri sendiri dengan proses penemuan sendiri. Ketujuh, strategi itu berpusat pada siswa bukan pada guru. Guru hanya sebagai teman belajar dan membantu apabila diperlukan

Selain memiliki keunggulan, model discovery learning juga memiliki kelemahan-kelemahan. Menurut Roestiyah (2008:21), model discovery learning memiliki lima kelemahan. Pertama, pada siswa harus ada kesiapan dan kematangan mental untuk cara belajar ini. Siswa harus berani dan berkeinginan untuk mengetahui keadaan sekitarnya dengan baik. Kedua, bila kelas terlalu besar penggunaan metode ini kurang berhasil. Ketiga, bila guru dan siswa sudah biasa dengan perencanaan dan pengajaran tradisional mungkin akan sangat kecewa bila diganti dengan model ini. Keempat, dengan model ini, ada yang berpendapat bahwa proses mental itu terlalu mementingkan proses pengertian saja, kurang memperhatikan perkembangan/pembentukan sikap dan keterampilan siswa. Kelima, model ini mungkin tidak memberikan kesempatan kepada siswa untuk berpikir secara kreatif.

Kelebihan-kelebihan tersebut salah satu alasan dipilihnya model discovery learning dalam pembelajaran menulis karangan argumentasi siswa kelas X SMA Negeri. Penggunaan model discovery learning bertujuan agar siswa mudah memahami dan menemukan teknik pengembangan karangan argumentasi, pemaparan fakta sebagai bukti, dan ketepatan penggunaan Ejaan Bahasa Indonesia. Selain itu, penggunaan model ini juga menarik perhatian siswa untuk lebih aktif berbicara di depan umum. Dengan demikan, tujuan penelitian ini adalah untuk melihat ada atau tidaknya pengaruh model discovery learning terhadap keterampilan menulis karangan argumentasi siswa kelas X SMA Negeri 3 Pariaman. 


\section{B. Metode Penelitian}

Jenis penelitian ini adalah penelitian kuantitatif dengan metode eksperimen. Arikunto (2010:10) mengemukakan bahwa penelitian kuantitatif merupakan penelitian yang menggunakan angka dimulai dari pengumpulan data, kemudian penafsiran data dan terakhir hasilnya. Metode yang digunakan dalam penelitian ini adalah metode eksperimen. Metode ini tepat digunakan karena penelitian ini bertujuan untuk melihat pengaruh perlakuan terhadap suatu objek penelitaian. Menurut Ibnu (2003), menyatakan penelitian eksperimental merupakan penelitian yang subjeknya diberi perlakuan kemudian diukur akibat dari perlakuan dari diri subjek. Jenis eksperimen ini adalah quasi eksperimen (eksperimen semu). Menurut Suryabrata (2011:92) eksperimen semu bertujuan untuk memperoleh informasi yang merupakan perkiraan bagi informasi yang dapat diperoleh dengan eksperimen yang sebenarnnya dalam keadaan yang tidak memungkinkan untuk mengontrol dan memanipulasi semua variabel yang relevan.

Penelitian ini dilakukan untuk mengetahui ada atau tidaknya pengaruh model discovery learning terhadap keterampilan menulis karangan argumentasi siswa kelas X SMA Negeri3 Pariaman. Indikator penilaian yang digunakan terdiri atas tiga, yaitu teknik pengemabangan karangan argumentasi (pendahuluan, tubuh argumen, dan simpulan), pemaparan fakta sebagai bukti, dan ketepatan penggunaan Ejaan Bahasa Indonesia (EBI). Dengan kata lain, hasil tes siswa dinilai berdasarkan ketiga indikator tersebut.

Sampel penelitian ini terdiri atas 2 kelompok.. Sampel yang diambil adalah kelas X.1 dengan jumlah siswa 30 orang dan kelas X.2 dengan jumlah siswa 31 orang dengan alasan kelas tersebut memiliki standar deviasi terendah dari tujuh kelas lainnya. Kelompok tersebut diberikan perlakuan berupa tes keterampilan menulis karangan argumentasi sebelum dan sesudah menggunakan model discovery learning.

Data penelitian ini adalah hasil tes keterampilan menulis karangan argumentasi tanpa dan menggunakan perlakuan. Data yang diperoleh selanjutnya dianalisis melalui langkah-langkah berikut. Pertama, melakukan penelitian terhadap keterampilan menulis karangan argumentasi ketika latihan dilaksanakan. Penilaian dilakukan dengan cara mencatat skor yang diperoleh siswa berdasarkan indikator yang dinilai dengan menggunakan rubrik penialian keterampilan menulis karangan argumentasi. Kedua, melakukan penilaian terhadap keterampilan menulis karangan argumentasi ketika posttest dilakukan. Penilaian dilakukan dengan cara mencatat skor yang diperoleh siswa berdasarkan indikator yang dinilai dengan menggunakan rubrik penilaian keterampilan menulis karangan argumentasi. Ketiga, menafsirkan keterampilan menulis karangan argumentasi dengan menggunakan model discovery learning berdasarkan nilai ratarata hitung. Keempat mengklasifikasikan keterampilan menulis karangan argumentasi siswa kelas X SMA Negeri 3 Pariaman dengan menggunakan skala 10. Kelima, sebelum melakukan uji hipotesis terlebih dahulu dilakukan menklasifikasikan uji normalitas dan uji homogenitas. Keenam, melakukan pengujian hipotesis. Ketujuh, menganalisis dan menyimpulkan hasil pembahasan.

\section{Hasil dan Pembahasan}

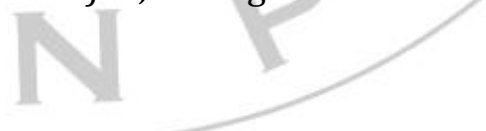

Dalam hasil dan pembahasan ini akan dijelaskan keterampilan menulis karangan argumentasi tanpa dan menggunakan model discovery learning serta menjelaskan bagaimana pengaruhnya terhadap keterampilan menulis karangan argumentasi siswa kelas X SMA Negeri 3 Pariaman.

Berdasarkan hasil pengamatan saat proses pembelajaran penggunaan model discovery learning sangat menarik dan cocok bagi siswa. Hal ini terbukti dengan antusiasme siswa untuk mengikuti pembelajaran. Pada saat pembelajaran berlangsung, siswa diperlakukan model discovery learning yang tealh disedikan. Ditinjau dari hasil tes keterampilan menulis karangan argumentasi yang diberikan kepada siswa, hasil tes dengan menggunakan model discovery learning lebihtinggi dibandingakan tanpa menggunakan model discovery learning. Kedua, keterampilan menulis karangan argumentasi siswa kelas X SMA Negeri 3 Pariaman tanpa menggunakan model descovery learning. 
Berdasarkan hasil pengamatan saat proses pembelajaran tanpa menggunakan model discovery learning siswa merasa cepat bosan dan tidak tertarik untuk mengikuti pembelajaran disebabkan media pembelajaran yang kurang dimanfaatkan secara maksimal oleh guru sehingga siswa cepat bosan, dan siswa kurang memiliki wawasan tentang fakta-fakta yang terjadi disekitar kehidupan mereka. Sehingga karangan yang dihasilkan siswa kurang baik dan berbobot. Ketiga, pengaruh penggunaan model discovery learning terhadap keterampilan menuilis karangan argumentasi siswa kelas X SMA Negeri 3 Pariaman. berdasarkan hasil pengamatan, diperoleh gambaran keterampilan menulis karangan argumentasi dengan menggunakan model discovery learning sangat berpengaruh terhadap keterampilan menulis karangan argumentasi siswa kelas X SMA Negeri 3 Pariaman dan model ini sangat baik diterapkan dalam pembelajaran menulis karangan argumentasi karena siswa lebih antusias, lebih aktif dan lebih termotivasi dalam proses pembelajaran dengan menggunakan model discovery learning karena siswa lebih merasa tertantang untuk menemukan dan merumuskan masalah baik secara kelo,pok maupun individu.

\section{Keterampilan Menulis Karangan Argumentasi Siswa Kelas X SMA 3 Pariaman dengan Menggunakan Model Discovery Learning}

Berdasarkan analisis data diperoleh rata-rata hitung keterampilan menulis karangan argumentasi siswa kelas X SMA Negeri 3 Pariaman menggunakan model discovery learning sebesar 78,51. Dari rata-rata hitung tersebut dapat disimpulkan bahwa keterampilan menulis karangan argumentasi siswa kelas X SMA Negeri 3 Pariaman menggunakan model discovery leaning berada pada kualifikasi baik.

Selain pembahasan secara umum, keterampilan menulis karangan argumentasi siswa kelas X SMA Negeri 3 Pariaman dengan menggunakan model pembelajaran discovery learning dapat dilakukan dengan analisis per indikator. Adapun indikator yang dinilai sebagai berikut. Pertama, menulis karangan argumentasi sesuai dengan Teknik Pengembangan Karangan Argumentasi (Pendahuluan, Tubuh Argumen, dan Penutup). Rata-rata hitung keterampilan menulis karangan argumentasi siswa kelas X SMA Negeri 3 Pariaman dengan menggunakan model discovery learning untuk indikator I menulis karangan argumentasi sesuai dengan teknik pengembangan karangan argumentasi (pendahuluan, tubuh argumen, dan penutup) adalah 82,22 berkualifikasi Baik (B). Hal ini disebabkan dalam pembelajaran menulis karangan argumentasi menggunakan model discovery learning siswa diberikan contoh yang dapat dijadikan sebagai pedoman dalam nemnulis karangan argumentasi. Siswa dapat diinstruksikan untuk menemukan teknik pengembangan karangan argumentasi dari contoh karangan argumentasi yang dibagikan.

Dengan demikian, ketika diberikan posttet siswa sudah tahu konsep teknik pengembangan karangan argumentasi dengan baik. Hal tersebut sejalan dengan (Mizani, 2015: 19), teknik pengembangan karangan argumentasi ada tiga, yaitu (a) pendahuluan, (b) tubuh argumen, dan (c) kesimpulan. Pendahuluan berisi tentang pembahasan pentingnya persoalan itu dibahas saat ini. Tubuh argumen berisi pembahasan masalah dengan dengan menyajikan fakta-fakta. Keimpulan berisi tentang kesimpulan-kesimpulan suatu pembahasan. Dari analisis tulisan karangan argumentasi siswa menggunakan model discovery learning diketahui bahwa 21 siswa menuliskan karangan argumentasi sesuai dengan teknik pengembangan karangan argumentasi (pendahuluan, tubuh argumen, dan kesimpulan).

Kedua, memaparkan fakta sebagai bukti. Rata-rata hitung keterampilan menulis karangan argumentasi siswa kelas X SMA Negeri 3 Pariaman adalah 75,55 berkualifikasi (Lebih dari Cukup) jika dilihat dari karangan argumentasi yang ditulis siswa dengan Baik menggunakan model discovery learning, terlihat bahwa dalam karangan tersebut siswa sudah terampil menuliskan paragraf yang mengandung argumen, atau pendapat, data, dan fakta-fakta yang dapat dibuktikan kebenarannya. Hal ini sejalan dengan (Darmayanti, 2014: 176) karangan argumentasi adalah paragraf yang pola pengembangannya berdasarkan argumen yang menyertakan fakta-fakta. Karangan argumentasi mengadirkan informasi tentang suatu hal secara apa adanya lalu dikelompokkan dan dianalisis secara sistematis sehingga dapat 
menjelaskan suatu hal secara rinci. Dari analisis tulisan karangan argumentasi siswa dengan menggunakan model discovery learning, dketahui bahwa 14 siswa menuliskan karangan argumentasi sesuai dengan pemaparan fakta sebagai bukti.

Ketiga, ketepatan penggunaan Ejaan Bahasa Indonesia. Rata-rata hitung keterampilan menulis karangan argumentasi siswa kelas X SMA Negeri 3 Pariaman dengan menggunakan model discovery learning adalah 77,77 berkualifikasi Baik (B). Dari analisis tulisan karangan argumentai siswa dengan menggunakan model discovery learning, diketahui bahwa tidak 17 siswa suda menuliskan karangan argumentasi sesuai dengan Ketepatan penggunaan Ejaan Bahasa Indonesia (EBI).

Keterampilan menulis karangan argumentasi siswa kelas X SMA Negeri 3 Pariaman dengan menggunakan model discovery learning dapat disimpulkan bahwa siswa lebih aktif dan memahami pelajaran yang diajarkan. Siswa dituntut mencari, menggali, dan menyimpulkan masalah yang dihadapinya. Siswa secara aktif memperhatikan tema yang telah ditentukan. Siswa mengisi format, kemudian mengidentifikasi pengelompokan kelas kata, lalu menuliskannya dalam sebuah karangan argumentasi dari fakta yang ditemukan dari tema tersebut. Kemudian, Jika di bandingkan dengan KKM mata pelajaran bahasa Indonesia kelas X SMA Negeri 3 Pariaman yaitu 75 disimpulkan bahwa keterampilan menulis karangan argumentasi siswa kelas X SMA Negeri 3 Pariaman dengan menggunakan model discovery learning sudah memenuhi KKM.

\section{Keterampilan Menulis Karangan Argumentasi Siswa Kelas X SMA 3 Pariaman tanpa Menggunakan Model Discovery Learning}

Berdasarkan analisis data diperoleh rata-rata hitung keterampilan menulis karangan argumentasi siswa kelas X SMA Negeri 3 Pariaman tanpa menggunakan model discovery learning sebesar 63,08. Dari rata-rata hitung tersebut dapat disimpulkan bahwa keterampilan menulis karangan argumentasi kelas X SMA Negeri 3 Pariaman tanpa menggunakan model discovery learning berkualifikasi Cukup (C).

Selain menggunakan rata-rata hitung (M) sebagai tolak ukur, maka untuk menentukan keterampilan menulis karangan argumentasi siswa kelas X SMA Negeri 3 Pariaman tanpa menggunakan model discovery learning dapat menggunakan KKM. KKM yang ditetapkan untuk mata pelajaran bahasa Indonesia kelas X SMA Negeri 3 Pariaman yaitu 75. Oleh karena itu, keterampilan menulis karangan argumentasi siswa kelas X SMA Negeri 3 Pariaman lebih rendah dari KKM yang ditentukan.

Keterampilan menulis karangan argumentasi siswa kelas X SMA Negeri 3 Pariaman tanpa menggunakan model pembelajaran discovery learning dapat dilakukan dengan analisis per indikator. Adapun indikator yang dinilai sebagai berikut. Pertama, menulis karangan argumentasi sesuai dengan teknik pengembangan karangan argumentasi (pendahuluan, tubuh argumen, dan penutup). Rata-rata hitung keterampilan menulis karangan argumentasi siswa kelas X SMA Negeri 3 Pariaman tanpa menggunakan model discovery learning untuk indikator I (menulis karangan argumentasi sesuai dengan teknik pengembangan karangan argumentasi (pendahuluan, tubuh argumen, dan penutup) berkualifikasi Baik (B). Hal ini disebabkan karena terbatasnya pengetahuan siswa mengenai teknik pengembangan karangan argumentasi (pendahuluan, tubuh argumen, dan kesimpulan). Di samping itu, siswa kurang memahami teknik pengembangan karangan argumentasi karena kebanyakan siswa menyamakan teknik pendahuluan dan tubuh argumen. tidak sejalan dengan (Mizani, 2015: 19), teknik pengembangan karangan argumentasi ada tiga, yaitu (a) pendahuluan, (b) tubuh argumen, dan (c) kesimpulan. Pendahuluan berisi tentang pembahasan pentingnya persoalan itu dibahas saat ini. Tubuh argumen berisi pembahasan masalah dengan dengan menyajikan fakta-fakta. Keimpulan berisi tentang kesimpulan-kesimpulan suatu pembahasan. Dari analisis tulisan karangan argumentasi siswa tanpa menggunakan model discovery learning diketahui bahwa 19 siswa tidak menuliskan karangan argumentasi sesuai dengan teknik pengembangan karangan argumentasi (pendahuluan, tubuh argumen, dan kesimpulan). 
Kedua, memaparkan fakta sebagai bukti. Rata-rata hitung keterampilan menulis karangan argumentasi siswa kelas X SMA Negeri 3 Pariaman adalah 55,10 berkualifikasi (Hampir Cukup). Hal ini disebabkan kurangnya pemahaman siswa mengenai pemaparan fakta, siswa tidak bisa menuliskan fakta berdasarkan apa yang mereka lihat. Hal ini membuat karangan argumentasi yang ditulis tidak tepat dan membingungkan. Hal ini tidak sejalan dengan (Darmayanti, 2014: 176), karangan argumentasi adalah paragraf yang pola pengembangannya berdasarkan argumen yang menyertakan fakta-fakta. Karangan argumentasi mengadirkan informasi tentang suatu hal secara apa adanya lalu dikelompokkan dan dianalisis secara sistematis sehingga dapat menjelaskan suatu hal secara rinci. Dari analisis tulisan karangan argumentasi siswa tanpa menggunakan model discovery learning, diketahui bahwa 27 siswa tidak menuliskan karangan argumentasi sesuai dengan pemaparan fakta sebagai bukti.

Ketiga, ketepatan penggunaan Ejaan Bahasa Indonesia. Rata-rata hitung keterampilan menulis karangan argumentasi siswa kelas X SMA Negeri 3 Pariaman dengan menggunakan model discovery learning adalah 61,69 berkualifikasi Cukup (C). Hal tersebut disebabkan karena terbatasnya pengetahuan siswa tentang EBI yang telah ditetapkan. Dari analisis tulisan karangan argumentai siswa tanpa menggunakan model discovery learning, diketahui bahwa 13 siswa tidak menuliskan karangan argumentasi sesuai dengan ketepatan penggunaan Ejaan Bahasa Indonesia (EBI).

Keterampilan menulis karangan argumentasi siswa kelas X SMA Negeri 3 Pariaman tanpa menggunakan model discovery learning dapat disimpulkan bahwa siswa belum memenuhi KKM. Dalam penelitian menulis karangan argumentasi siswa kelas X SMA Negeri 3 Pariaman tanpa menggunakan model discovery learning disimpulkan tidak semua siswa aktif dalam proses belajar mengajar. Pada kelas kontrol penelitian menulis karangan argumentasi mengguankan strategi ceramah. Berikut adalah contoh karangan argumentasi yang ditulis siswa.

\section{Pengaruh Model Discovery Learning dalam Pembelajaran Menulis Karangan Argumentasi Siswa Kelas X SMA Negeri 3 Pariaman}

Model pembelajaran discovery learning sangat baik jika diterapkan dalam pembelajaran menulis karangan argumentasi. Siswa terlihat lebih antusias, lebih aktif, dan lebih termotivasi dalam proses pembelajaran dengan menggunakan model discovery learning karena siswa merasa lebih tertantang untuk menemukan dan merumuskan masalah baik secara kelompok atau individu. Hal ini sejalan dengan pendapat Tumurun $(2016 ; 103)$, model discovery learning merupakan model model pembelajaran yang mampu untuk mengembangkan keterampilan berpikir kreatif, diantaranya menemukan masalah dan merumuskan masalah. Selain itu model discovery learning adalah metode mengajar yang mengatur pengajaran sedemikian rupa sehingga anak memperoleh pengetahuan yang sebelumnya belum diketahuinya tanpa pemberitahuan langsung, sebagian atau seluruhnya ditemukan sendiri (Supriyanto, 2014: 167).

Model pembelajaran discovery learning merupakan salah satu model pembelajaran dimana guru tidak langsung memberikan hasil akhir atau kesimpulan dari materi yang disampaikannya. Melainkan siswa diberi kesempatan mencari dan menemukan hasil data tersebut. Sehingga proses pembelajaran ini yang akan diingat oleh siswa sepanjang masa, sehingga hasil yang ia dapat tidak mudah dilupakan. Hal ini sejalan dengan pendapat Muhamad (2016: 12), model discovery learning adalah proses belajar yang di dalamnya tidak disajikan suatu konsep dalam bentuk jadi (final), tetapi siswa dituntut untuk mengorganisasi sendiri cara belajarnya dalam menemukan konsep. Semua siswa memiliki memiliki potensi kreatif yang harus dikembangkan agar mereka mampu hidup penuh gairah dan produktif dalam melakukan tugas-tugasnya, maka kreativitas siswa harus dikembangkan secara optimal dalam situasi belajar mengajar dengan menggunakan metode pembelajaran yang tepat. Kreativitas dapat dikembangkan melalui belajar penemuan masalah.

Ditinjau dari hasil tes keterampilan menulis karangan argumentasi yang diberikan kepada siswa, hasil tes dengan menggunakan model discovery learning lebih tinggi dibandingkan dengan tanpa menggunakan model discovery learning. hal ini terbukti dengan hasil penelitian yang 
menunjukkan bahwa keterampilan menulis karangan argumentasi dengan menggunakan model discovery learning siswa kelas X SMA Negeri 3 Pariaman berada pada kualifikasi baik, sedangkan keterampilan menulis karangan argumentasi siswa tanpa menggunakan model discovery learning berada pada kualifikasi cukup. Demikian juga halnya dengan uji hipotesis yang dilakukan bahwa $t_{\text {tabel }}<t_{\text {hitung }}(1,70<6,20)$.

Berdasarkan hasil analisis data, diperoleh gambaran tentang keterampilan menulis karangan argumentasi dengan menggunakan model discovery learning dan tanpa menggunakan model discovery learning siswa kelas X SMA Negeri 3 Pariaman yang berupa temuan positif dan temuan negatif. Temuan positif tersebut antara lain (1) siswa kelas X SMA Negeri 3 Pariaman sudah terampil menulis karngan argumentasi dengan menggunakan model discovery learning dilihat dari indikator menulis karangan argumentasi dengan teknik pengembangan karangan argumentasi (pendahulan, tubuh argumen, dan kesimpulan), memaparkan fakta sebagai bukti, dan ketepatan penggunaan Ejaan Bahasa Indonesia (EBI); (2) siswa kelas X SMA Negeri 3 Pariaman lebih terampil menulis karangan argumentasi dengan menggunakan model discovery learning dilihat dari indikator menulis karangan argumentasi dengan teknik pengembangan karangan argumentasi (pendahulan, tubuh argumen, dan kesimpulan), memaparkan fakta sebagai bukti, dan ketepatan penggunaan Ejaan Bahasa Indonesia (EBI). Hal ini dibuktikan dengan nilai rata-rata keterampilan menulis karangan argumentasi siswa kelas X SMA Negeri 3 Pariaman dengan menggunakan model discovery learning lebih tinggi daripada tanpa menggunakan model discovery learning.

Selanjutnya, temuan negatif penelitian ini adalah bahwa keterampilan menulis karangan argumentasi siswa kelas X SMA Negeri 3 Pariaman tanpa menggunakan model discovery learning berada pada kualifikasi cukup dengan nilai rata-rata 63,08. Faktor tersebut diakibatkan oleh siswa yang hanya mendengarkan penjelasan guru. Siswa tidak menemukan sendiri materi dari sebuah karangan argumentasi tetapi guru yang memberikan. Sehingga dalam tes menulis karangan argumentasi siswa mengalami kesulitan untuk menulis karngan argumentasi.

Berdasarkan uraian di atas, disimpulkan bahwa guru sangat berperan penting dalam merencanakan, melaksanakan, mengevaluasi dan memberikan variasi pembelajaran kepada siswa agar tidak cepat bosan dalam belajar khususnya menulis karangan argumentasi. Salah satu upaya tersebut berupa penggunaan model discovery learning dalam pembelajaran karangan argumentasi. Model discovery learning dapat mempermudah siswa memperoleh informasi yang dibutuhkan melalui diskusi.

Perbedaan rata-rata keterampilan menulis karangan argumentasi dengan menggunakan model discovery learning dan tanpa menggunakan model discovery learning siswa kelas X SMA Negeri 3 Pariaman, dianggap sebagai pengaruh yang ditimbulkan oleh penggunaan model discovery learning yang diberikan pada siswa kelas X SMA Negeri 3 Pariaman. Dengan demikian, disimpulkan bahwa ada pengaruh yang signifikan terhadap penggunaan model discovery learning dalam pembelajaran keterampilan menulis karangan argumentasi siswa kelas X SMA Negeri 3 Pariaman.

\section{Simpulan dan Saran}

Berdasarkan hasil analisis data dan pembahasan pada bab IV, dapat disimpulkan hal-hal sebagai berikut ini.

Pertama, keterampilan menulis karangan argumentasi siswa kelas X SMA Negeri 3 Pariaman tanpa mengguankan model discovery learning berada pada kualifikasi cukup. Keterampilan menulis karangan argumentasi siswa kelas X SMA Negeri 3 Pariaman tanpa menggunakan model discovery learning berdasarkan kualifikasi cukup belum tuntas. Hal ini disebabkan siswa kesulitan dalam menulis karangan argumentasi sesuai dengan indikator yang ditetapkan.

Kedua, keterampilan menulis karngan argumentasi siswa kelas X SMA Negeri 3 Pariaman dengan menggunakan model discovery learning berada pada kualifikasi baik. Keterampilan 
menulis karangan argumentasi siswa kelas X SMA Negeri 3 Pariaman menggunakan model discovery learningberdasarkan kualifikasi baik sudah tuntas. Hal ini disebabkan siswa diminta untuk membaca terlebih dahulu referensi yang sesuai dengan materi karangan argumentasi dan melakukan pengumpulan data yang dilakukan secara perorangan. Kegiatan tersebut membantu untuk menulis karangan argumentasi dengan indikator yang telah ditetapkan.

Ketiga, berdasarkan hasil uji-t disimpulkan bahwa penggunaan model discovery learning berpengaruh terhadap keterampilan menulis karangan argumentasi siswa kelas X SMA Negeri 3 Pariaman. Dengan kata lain model discovery learning dapat diterapkan dalam pembelajaran menulis karangan argumentasi. Dengan demikian, $H_{1}$ diterima dan $H_{0}$ ditolak karena hasil penelitian membuktikan bahwa $t_{\text {tabel }}<t_{\text {hitung }}$.

\section{E. Saran}

Berdasarkan simpulan di atas, diajukan tiga saran berikut. Pertama, disarankan kepada guru mata pelajaran bahasa Indonesia kelas X SMA Negeri 3 Pariaman untuk lebih memvariasikan model dan media pembelajaran, khususnya dalam pembelajaran keterampilan menulis karangan argumentasi. Hal ini disebabkan model pembelajaran sangat berperan penting untuk mewujudkan tujuan pembelajaran. Kedua, disarankan kepada siswa kelas X SMA Negeri 3 Pariaman untuk lebih banyak berlatih menulis baik di sekolah maupun diluar sekolah, agar keterampilan dalam menulis terutama menulis karangan argumentasi dapat dikuasai dengan baik. Ketiga, bagi penelitian lain, sebagai masukan dari perbandingan dalam melakukan penelitian yang berkaitan dengan masalah ini. Dengan adanya membandingankan dari si peneliti lain, akan menjadi acuan dalam melakukan penelitian yang menggunakan model pembelajaran yang berbeda. Keempat, bagi dunia pendidikan lebih memperhatikan lagi sarana dan prasarana yang dibutuhkan dalam pembelajaran, khususnya pembelajaran bahasa Indonesia. Pembelajaran bahasa Indonesia yang mengguankan sarana yang bervariasi akan menjadikan siswa lebih aktif dan memahami pelajaran lebih baik lagi.

Catatan: Artikel ini disusun berdasarkan skripsi Elsalailatun dengan Pembimbing I Prof. Dr. Syahrul R., M.Pd. dan Pembimbing II Dr. Tressyalina, M.Pd.

\section{Daftar Rujukan}

Arikunto, S. (2010). Prosedur Penelitian: Suatu Pendekatan Praktik. Jakarta: Rineka Cipta.

Ambarwati, Y., Andayani, dan Rakhmawati, A . (2015). Pembelajaran Keterampilan Menulis Karangan Argumentasi (Studi Kasus di Kelas X Tata Busanabutik SMK Negeri 4 Sukoharjo. Jurnal Penelitian Bahasa, Sastra Indonesia dan Pengajarannya 3 (2), 4.

Darmayanti, I. A. M. (2014). Peningkatan Keterampilan Menulis Paragraf Argumentasi Melalui Pembelajaran Berbasis Masalah. Jurnal Pendidikan dan Pengajaran 2 (47), 145-154.

Emidar dan Ermanto. (2015). Pengembangan Kepribadian diperguruan Tinggi. Padang: UNP Prees.

Gani, E. (2012). Bahasa Karya Tulis Ilmiah. Padang: UNP PRESS.

Gani, E. (2013). Menulis Karya Ilmiah Teori dan Terapan: Padang: UNP PRESS.

Hasnum, A. (2006). Pedoman Menulis untuk Siswa SMP dan SMA. Yogyakarta: Andi Offset. 
Hosnan. (2014). Pendekatan Scientific dan Kontekstual dalam Pembelajaran Abad 21: Kunci Sukses Implementasi Kurikulum 2013. Jakarta: Ghalia Indonesia.

Ibnu, S. (2003). Dasar- Dasar Metodologi Penelitian. Malang: Universitas Negeri Malang.

Idris, Y. (2014). Peningkatan Keterampilan Menulis Karangan Deskripsi Melalui Metode Discovery Learning dengan Menggunakan Media Gambar Mahasiswa Prodi Pendidikan Bahasa dan Sastra Indonesia Ta 2011/2012 Universitas Ekasakti Padang. Jurnal Bahasa, Sastra dan Pembelajaran, 2 (3), 6.

Mizani, N. (2015). Peningkatan Kemampuan Menulis Karangan Argumentasi dengan Motode Mind Mapping (Peta Pikiran) Siswa Kelas X SMA Muhammadiyah 25 Pamulang, Tangerang Selatan. Jurnal Bahasa 2 (2), 19.

Muhammad, N. (2016). Pengaruh Metode Discovery Learning untuk Meningkatkan Representasi Matematis dan Percaya Diri Siswa. Uurnal Pendidikan Universitas Garut 09 (01), 9-22.

Rahzanie, R. D. (2011). Peningkatan Keterampilan Menulis Karangan Argumentasi Menggunakan Metode Kontekstual dengan Media Pembelajaran Berbasis ICT Padasiswa Kelas X 3sma Negeri 2 Temanggung. Jurnal Pendidikan Penabur 2 (05), 4.

Roestiyah, N.K. (2008). Strategi Belajar Mengajar. Jakarta: Rineka Cipta.

Rudyanto, H. E. (2012). Model Discovery Learning dengan Pendekatan Saintifik Bermuatan Karakter untuk Meningkatkan Kemampuan Berpikir Kreatif. Jurnal Sains Terapan 2 (1), 8.

Supriyanto, B. (2014). Penerapan Discovery Learning untuk Meningkatkan Hasil Belajar Siswa Kelas VI B Mata Pelajaran Matematika Pokok Bahasan Keliling dan Luas Lingkaran di SDN Tanggul Wetan 02 Kecamatan Tanggul Kabupaten Jember. Pancaran 3 (2), 167.

Suryabrata, S. (2011). Metodologi Penelitian. Jakarta: Raja Grafindo Persada.

Tumurun, W. S. (2016). Pengaruh Model Discovery Learning terhadap Keterampilan Berpikir Kreatif Siswa pada Materi Sifat-Sifat Cahaya. Jurnal Pena Ilmiah 1 (1), 103.

Widianyana, W. (2014). Pengaruh Model Discovery Learning Terhadap Pemahaman Konsep IPA dan Sikap Ilmiah Siswa SMP. e-Jurnal sains, 2 (1), 11. 